\title{
PERANAN KEPEMIMPINAN DALAM PEMBANGUNAN FISIK DI DESA KULO KECAMATAN KULO KABUPATEN SIDENRENG
}

\author{
1)Megaria, ${ }^{2)}$ Hariyanti Hamid, ${ }^{3)}$ Andi Astinah Adnan \\ Fakultas IImu Sosial dan IImu Politik Universitas Muhammadiyah Sidenreng Rappang \\ megariaega43152150.1c@gamil.com \\ tantistisip@yahoo.co.id \\ andi.astinah.adnan@gmail.com
}

\begin{abstract}
Abstrak
Tujuan penelitian yaitu untuk mengetahui peranan kepemimpinan kepala desa dalam pembangunan fisik di Desa Kulo Kecamatan Kulo kabupaten Sidenreng Rappang dan Faktorfaktor yang memengaruhi peranan kepemimpinan kepala desa dalam pembangunan fisik di Desa Kulo Kecamatan Kulo Kabupaten Sidenreng Rappang. Metode penelitian deskriptif kuantitatif. Populasi penelitian yaitu seluruh masyarakat Desa Kulo Kecamatan Kulo berjumlah 3039 jiwa, penentuan sampel menggunakan sampel acak, dengan sampel dalam penelitian ini yaitu 97 orang. Hasil penelitian menunjukkan bahwa variabel $(x)$ peranan kepemimpinan kepala desa adalah $49,67 \%$ kategori kurang baik. Demikian untuk hasil data akhir pada kedua variabel menunjukkan bahwa peranan kepemimpinan kepala desa dalam pembangunan fisik di Desa Kulo Kecamatan Kulo Kabupaten Sidenreng Rappang adalah 50\% dikategorikan kurang baik. Faktorfaktor yang memengaruhi peranan kepemimpinan kepala desa di Desa Kulo Kecamatan Kulo Kabupaten Sidenreng Rappang adalah Sumber daya manusia (7\%), Sumber dana (21\%), Partisipasi masyarakat (29\%).
\end{abstract}

Kata Kunci : Kepemimpinan kepala desa, pembangunan fisik

\begin{abstract}
The research objective is to determine: 1 . the role of village leadership in physical development in the village of Kulo, Kulo District, Sidenreng Rappang Regency 2. Factors that influence the leadership role of the village head in physical development in the Kulo Village, Kulo District, Sidenreng Rappang Regency.Descriptive quantitative research methods. The population of the research is the entire community of Kulo Village, Kulo District, amounting to 3039 people, the determination of the sample using a random sample, with the sample in this study is 97 people. The results showed that the variable $(x)$ the leadership role of the village head was $49.67 \%$ of the unfavorable category produced while the expected 100. Likewise for the final data results on both variables indicate that the role of leadership of the village head in physical development in the Village of Kulo, Kulo District, Sidenreng Rappang Regency is $50 \%$ categorized as not good. Factors influencing the leadership role of village heads in Kulo Village, Kulo District, Sidenreng Rappang Regency are: Human resources (7\%), Sources of funds (21\%), Community participation (29\%).
\end{abstract}

Keywords: Village head leadership, physical development 


\section{A. PENDAHULUAN}

Menurut Undang-Undang No 25 Tahun 2004 tentang Sistem Pembangunan Nasional bahwa Pembangunan Nasional adalah upaya yang dilaksanakan oleh semua komponen bangsa dalam rangka mencapai tujuan bernegara. Pada konsepsi ini bahwa pembangunan nasional menitikberatkan pada komponen yang ada pada suatu negara tersebut. Komponen bangsa harus saling bersinergi dan saling mengisi untuk tercapainya suatu tujuan pembangunan nasional tersebut. Tujuan pembangunan nasional tersebut pada hakikatya adalah untuk tercapainya kesejahteraan masyarakat yang ada di dalam Negara Kesatuan Republik Indonesia. Perencanaan pembangunan nasional yang dilaksanakan pemerintah mencangkup beberapa tahapan yang ada di dalamnya. Proses perencanaan pembangunan ini penyelenggaraan perencanaan makro semua fungsi yang meliputi semua bidang kehidupan secara terpadu dalam wilayah Negara Republik Indonesia. Pada tataran selanjutnya Perencanaan Pembangunan Nasional disusun secara terpadu oleh Kementerian/Lembaga dan Perencanaan Pembangunan oleh Pemerintah Daerah sesuai dengan kewenangannya. Perencanaan Pembangunan yang paling terkecil dalam struktur ketatanegaraan di Indonesia adalahpembangunan yang berasal dari suatu desa.

Pembangunan desa meliputi tahap perencanaan, pelaksanaan, dan pengawasan. Keberadaan infrastruktur fisik yang baik seperti halnya jalan, jembatan, sarana telekomunikasi, sarana perlistrikan, sarana irigasi dan sarana transportasi juga sering dikaitkan sebagai pemicu perkembangan pembangunan diberbagai bidang pada suatu kawasan. Pembangunan desa bertujuan meningkatkan kualitas sumber daya manusia, termasuk penciptaan iklim yang mendorong tumbuh prakarsa dan swadaya masyarakat desa. Penduduk pedesaan merupakan suatu potensi sumber daya manusia yang memiliki peran ganda, yaitu sebagai obyek dan subjek pembangunan. Pemerintahan desa merupakan ujung tombak pembangunan nasional yang dipimpin oleh seorang kepala desa sebagai pemegang pucuk pimpinan tertinggi di desa, sebagai penentu utama dalam mencapai keberhasilan pembangunan desa. Oleh karena itu kepala desa harus mampu melaksanakan tugas dan fungsinya dengan baik dalam proses penyelenggaraan pembangunan dan mengembangkan kehidupan masyarakatnya kearah tujuan yang telah direncanakan. Menurut UU No. 6 tahun 2014 tentang desa Pasal 1 ayat (8) yang berbunyi: "Pembangunan desa adalah upaya peningkatan kualitas hidup dan kehidupan untuk sebesar-besarnya kesejahteraan masyarakat desa".

$$
\text { Pembangunan adalah proses }
$$

perubahan sistem yang direncanakan kearah perbaikan yang orientasinya pada modernis pembangunan dan kemajuan sosial ekonomis. Konsep pembangunan itu merupakan kunci pembuka bagi pengertian baru tentang hakekat fungsi administrasi pada setiap negara dan sifat dinamis. Pembangunan akan dapat berjalan lancar apabila disertai dengan administrasi yang baik. adapun Indikator keberhasilan pembangunan dapat dilihat, 1)sejauh mana kondisi dan taraf hidup masyarakat berhasil ditingkatkan. 2)sejauh mana keikutsertaan masyarakat dalam pembangunan berhasil digerakkan, dan 3)sejauh mana kemampuan masyarakat untuk berkembang secara mandiri (Basri, 2005).

Hubungan antara pemimpin dan rakyat merupakan hal yang mutlak karena keduanya saling membutuhkan dan saling melengkapi. Menurut (Saiman, 2009) bahwa seorang pemimpin harus memiliki sifat-sifat sebagai berikut : a) pendidikan umum yang luas, dengan pendidikan umum yang luas maka kita akan lebih mudah memecahkan masalah yang dihadapi b)kematangan mental,dengan mental yang matang, seorang pemimpin akan dapat mengendalikan emosinya pada saat mengambil tindakan dari tugas yang embannya. c)sifat ingin tahu, dengan sifat ini seorang pemimpin menjadi mudah menyesuaikan diri dengan perubahan yang terjadi disekitarnya. jadi kepemimpinan sangat penting dalam menentukan keberhasilan pembangunan yang efektif dan efisien, karena di dalam kepemimpinan terkandung unsur bagaimana mempengaruhi orang lain untuk mencapai tujuan yang sudah ditetapkan terlebih dulu.

Kepemimpinan kepala desa juga merupakan salah satu aspek yang menonjol dan berpengaruh terhadap keberhasilan pembangunan desa, desa dalam hal ini adalah organisasi sangat dipengaruhi oleh 
pemimpin keadaan ini sesuai dengan pendapat (Hasibuan, 2003) "Kepemimpinan adalah cara seorang pemimpin mempengaruhi perilaku bawahan agar mau bekerja sama dan bekerja secara efektif dan efisien untuk mencapai tujuan organisasi".

Kepala desa juga seharusnya berperan dalam membangun kesadaran masyarakat untuk berpartisipasi terhadap programprogram yang dilakukan oleh pemerintah desa serta mampu menyusun kebijakan strategis yang melibatkan masyarakat. Masyarakat juga bagian dari suksesnya pelaksanaan program desa, masyarakat juga mempunyai peranan terhadap tercapainya tujuan dari pembangunan. Suatu koordinasi yang baik antara pemerintah dan masyarakat tentunya diharapkan dapat mewujudkan pembangunan di desa khususnya di Desa Kulo Kecamatan Kulo. Pada kenyataannya proses pembangunan yang ada di Desa Kulo belum terlaksana dengan baik, hal ini dapat terlihat pada tabel dibawah ini: yaitu program RPJM Desa Kulo 2017/2018 Pembangunan fisik yang menjadi program utama.

Tabel 1.1

Pembangunan fisik di Desa Kulo

\begin{tabular}{|c|c|c|c|}
\hline $\begin{array}{l}\mathbf{N} \\
\mathbf{O}\end{array}$ & Pembangunan fisik & $\begin{array}{l}\text { Terla } \\
\text { ksana }\end{array}$ & $\begin{array}{l}\text { Tidak } \\
\text { terlak } \\
\text { sana } \\
\end{array}$ \\
\hline 1. & Balai desa & $\mathrm{Ya}$ & - \\
\hline 2. & $\begin{array}{l}\text { Betonisasi jalan } \\
\text { poros Kulo }\end{array}$ & $\mathrm{Ya}$ & - \\
\hline 3. & $\begin{array}{l}\text { Pembangunan rabat } \\
\text { beton SD } 1 \text { Kulo }\end{array}$ & - & Tidak \\
\hline 4. & $\begin{array}{ll}\text { Pengaspalan } & \text { cor } \\
\text { beton jalur II. } & \end{array}$ & - & Tidak \\
\hline 5. & $\begin{array}{l}\text { Pengaspalan jalan } \\
\text { pemukiman Kaboe } \\
\text { menghubungkan } \\
\text { jalan tani }\end{array}$ & - & Tidak \\
\hline 6. & Jembatan & - & Tidak \\
\hline
\end{tabular}

Sumber : Data Profil Desa Kulo 2017/2018

Tabel di atas menggambarkan bahwa pembangunan yang ada di Desa Kulo tidak berjalan dengan optimal. Berdasarkan observasi awal peneliti mewawancarai salah satu warga yang berinisial (M) beliau mengatakan bahwa pembangunan yang ada di Desa Kulo sudah ada yang berjalan, tetapi menurut beliau dari sekian banyak rencana pembangunan di Desa Kulo yang telah berjalan hanya seperempat bagian dari seluruh rencana pembangunan tersebut masih ada pembangunan sampai sekarang belum terlaksana salah satunya pembangunan fisik.

Maka dengan hasil observasi dan asumsi awal dan melihat dari beberapa data yang menyakut masalah pembangunan fisik di Desa Kulo Kecamatan Kulo calon peneliti menemukan masalah bahwa masih kurang baiknya pembangunan di Desa Kulo dalam hal pembangunan fisik masih belum merata atau tidak efektif. Hal ini harus disadari oleh pemimpin dan bawahanya supaya tidak saling menyalahkan sebagai pengelolah organisasi. Pemimpin diharapkan pula bersama-sama dapat turut adil dalam proses kinerja atau pelayanan agar tercipta komunikasi dan kerjasama yang baik antara pemerintah desa dan masyarakat. kepedulian pemimpin yang sangat diharapkan untuk menunjang keberhasilan pembangunan fisik di Desa Kulo Kecamatan Kulo Kabupaten Sidenreng Rappang. Untuk melihat masalah yang terjadi calon peneliti menggunakan teori kepemimpinan kepala desa menurut (Tjokromidjojo, 2003) yaitu 1. Mobilisator 2. Fasilitator 3. Motivator .

Berdasarkan uraian tersebut maka penulis tertarik mengambil judul. "Peranan Kepemimpinan Kepala Desa dalam Pembangunan Fisik di Desa Kulo Kecamatan Kulo Kabupaten Sidenreng Rappang dengan tujuan Untuk mengetahui Peranan Kepemimpinan Kepala Desa dalam Pembangunan Fisik di Desa Kulo Kecamatan Kulo, dan Untuk mengetahui faktor-faktor yang memengaruhi Peranan Kepemimpinan Kepala Desa dalam Pembangunan Fisik di Desa Kulo Kecamatan Kulo. Menurut Hersey dan Blanchart (Sunyoto, 2012)kepemimpinan adalah setiap upaya seseorang yang mencoba untuk mempengaruhi tingkah laku atau kelompok, upaya untuk mempengaruhi tingkah laku ini bertujuan mencapai tujuan perorangan, tujuan teman, atau bersamasama dengan tujuan organisasi yang mungkin sama atau berbeda.

Adapun teori (Tjokromidjojo, 2003) menyatakan tiga indikator sikap positif yang mengarah kepeningkatan dalam pelaksanaan peranan kepemimpinan sebagai berikut.

1. Motivator yaitu peran sebagai pendorong dan pemberi semnagat kepada masyarakat setempat, agar ikut melakukan tindakan-tindakan yang positif sehingga apa yang diharapkan dapat lebih 
berkembang dan suatu saat dapat menjadi penopang kesejahteraan masyarakat.

2. Fasilitator yaitu orang yang memberikan bantuan dan menjadi narasumber yang baik untuk sebagai permasalahan serta menfasilitasi kegiatan-kegiatan pelayanan desa memberikan kemudahan dan kelancaran dalam proses pembangunan sehingga dalam kegiatan desa dapat berjalan dengan baik.

3. Mobilisator yaitu orang yang mengarahkan atau menggerakkan untuk melakukan sesuatu yang berkaitan dengan sebuah pembangunan guna untuk kepentingan bersama. Jadi pemerintah desa sebagai mobilisator yanfg menggerakkan atau mengajak masyarakat untuk bersamasama melakukan tindakan yang nyata untuk membangun desa, misalnya gotong royong, melakukan penyuluhan, serta memperbaiki tempat-tempat umum lainnya.

Kata kunci dari konsep pembangunan adalah perubahan, pertumbuhan, pemenuhan kebutuhan, peningkatan martabat dan harga diri (Susanto, 2008) dalam strategi penggulangan kemiskinan tidak terlepas dari pembangunan itu sendiri. Menurut Korten (dkk, 2013) menyatakan konsep pembangunan berpusat pada rakyat memandang inisiatif kreatif dari rakyat sebagai sumber daya pembangunan yang utama dan memandang kesejahteraan material dan spritual mereka sebagai tujuan yang ingin dicapai oleh proses pembangunan.

Menurut (Sjafrizal, 2014) indikator tentang pembangunan :

1. Mendukung koordinasi antara pelaku pembangunan merupakan keterpaduan antara pelaku pembangunan baik dalam institusi pemerintah sendiri maupun pemerintahan antara pihak swasta dan msyarakat secara keseluruhan.

2. Menjamin terciptanya integrasi, singkronisasi dan sinergi antar daerah merupakan untuk dapat mendorong proses pembangunan secara lebih cepat dan efisien dengan demikian diperlukan adanya pengintegrasian proses perencanaan melalui musrenbang dari berbagai sumber pendanaan, sehingga diharapkan berbagai program prioritas pembangunan yang ditetapkan tepat sasaran.
p-ISSN 2302-0970

e-ISSN 2723-0201

3. Menjamin keterkaitan dan konsistensi antara perencanaan penganggaran, pelaksanaan dan pengawasan merupakan untuk dapat mewujudkan pembangunan sesuai sesuai dengan apa yang telah direncanakan semula, perlu dijamin semaksimal mungkin terdapatnya keterkaitan antara perencanaan, penganggaran, pelaksanaan dan pengawasan.

4. Mengoptimalkan partisipasi masyarakat dalam perencanaan pembangunan merupakan bagaimana partisipasi masyarakat tersebut dapat di manfaatkan dalam proses pembangunan seoptimal mungkin dalam perencanaan pembangunan, masyarakat tidak sematamata diperlakukan sebagai obyek, tetapi lebih sebagai subyek dan aktor atau pelaku (Soetomo, 2008)

5. Menjamin tercapainya sumber daya secara efisiensi, efektif dan adil. Merupakan tujuan dan fungsi utama dari perencanaan pembangunan dalam literatur adalah untuk menjamin terwujudnya penggunaan sumber daya, baik dana dan tenaga secara efektif, efisien, dan adil.

Menurut (S., 2013) faktor-faktor yang memengaruhi peranan kepemimpinan dalam pengembangan lebih lanjut secara partisipatif. Dengan adanya faktor internal dan eksternal diantaranya sebagai berikut :

1. Sumber daya manusia atau aparatur desa yang bertugas pada organisasi tersebut, kemampuan disiplin kerja untuk memberikan pelayanan yang baik terhadap masyarakat serta selalu siap untuk bekerja sama dalam melakukan kegiatan-kegiatan pembangunan, baik kepada instansi-instansi terkait maupun kepada masyarakat langsung.

2. Sumber dana adalah pemerintah daerah memberlakukan kebijakan tentang mengalokasikan anggaran untuk desa yang dapat digunakan oleh desa, yang merupakan hal yang dapat menunjang terselenggaranya proses kegiatan tersebut.

3. Partisipasi masyarakat, adanya kesadaran masyarakat yang memiliki kemauan, kemampuan, kesediaan, kesadaran, kerjasama, prakarsa (motivasi), wawasan yang kuat melekat pada diri anggota masyarakat terhadap pentingnya pembangunan. 


\section{B. METODE PENELITIAN}

Jenis metode yang digunakan untuk pengukuran adalah deskriptif kuantitatif, dengan metode ini diharapkan dapat memberikan gambaran secara cermat dan jelas. populasi dari keseluruhan masyarakat di Desa Kulo Kecamatan Kulo Kabupaten Sidenreng Rappangyang berjumlah 3.039 jiwa dan jumlah 557 KK.dengan Teknik pengambilan sampel dalam penelitian ini adalah sampel acak adalah teknik pengambilan anggota sampel dari populasi dilakukan secara acak tanpa memperhatikan strata yang ada dalam populasi itu Dengan menggunakan rumus taro yamana sampel dalam penelitian ini adalah 97 orang. Teknik pengumpulan data atau teknik survai menggunakan yaitu kuisioner/angket, wawancara dan dokumentasi, kemudian data yang diperoleh dikumpulkan dan dianalisis dengan teknik deksriptif kuantitatif menggunakan sistem tabulasi, frekuensi, persentase, dengan statistik bantuan aplikasi software SPSS 16.0.

\section{HASIL DAN PEMBAHASAN}

Berdasarkan hasil rekapitulasi yang diperoleh dari variabel $(X)$ peranan kepemimpinan kepala desa dengan persentase sebanyak $49,67 \%$ dan berada pada kategori kurang baik, hal tersebut menandakan bahwa penerapan indikator teori peranan kepemimpinan kepala desa (Tjokroadmidjojo 2003:42) berjalan dengan kurang baik di Desa Kulo hal tersebut ditandakan dari ke empat indikator hanya indikator Fasilitator kaitannya dengan Sumber Dana yang mempunyai persentase tertinggi yaitu $53,35 \%$ kategori baik indikator yang lain berada pada kategori kurang baik seperti Mobilisator persentase $50 \%$, Motivator dengan persentase 47,68\%, dan Fasilitator kaitanya dengan pengalokasian anggaran dengan persentase terendah $47,16 \%$. Persentase paling tertinggi dan paling terendah dalam kaitannya dengan teori (Tjokromidjojo, 2003) yaitu :

1. Indikator persentase tertinggi "fasilitator kaitanya dengan sumber dana berada pada persentase $53,35 \%$.

2. Indikator persentase terendah "fasilitator kaitannya dengan pengalokasian anggaran $47,16 \% "$

Berdasarkan hasil rekapitulasi yang diperoleh dari variabel (Y) pembangunan Fisik dengan persentase sebanyak 48,77\%
p-ISSN 2302-0970

e-ISSN 2723-0201

dan berada pada kategori kurang baik. Hal tersebut menandakan bahwa indikator pembangunan fisik (Sjafrizal, 2014) berjalan dengan kurang baik di Desa Kulo hal ini ditandai dari kedelapan indikator yang digunakan hanya indikator :

1. Menjamin terciptanya integritas sinkronisasi antara perencanaan dan pengawasan, dalam hal perencanaan pembangunan fisik dalam musrenbang desa yang menempati presentase tertinggi yaitu $57,9 \%$ baik.

2. Mendukung koordinasi antara pelaku pembangunan dalam hal peranan kepemimpinan kepala desa terhadap hubungan dengan pemerintah daerah dalam pembangunan fisik Desa Kulo $52,06 \%$ baik.

3. Mendukung koordinasi antara pelaku pembangunan dalam hal peranan kepemimpinan kepala desa terhadap hubungan dengan pihak swasta dalam pembangunan fisik Desa Kulo 51,03\% baik.

Indikator yang lain berada pada kategori kurang baik seperti :

1. Menjamin terciptanya integritas sinkronisasi antara perencanaan, pelaksanaa dan pengawasan, dalam hal perencanaan pendanaan dalam pembangunan fisik presentase $42,27 \%$ kategori kurang baik.

2. Menjamin terciptanya integritas sinkronisasi antara perencanaan, pelaksanaan dan pengawasan, dalam hal pelaksanaan pembangunan fisik presentase $42,53 \%$ kategori kurang baik.

3. Menjamin terciptanya integritas sinkronisasi antara perencanaan dan pengawasan, dalam hal pengawasan pembangunan fisik presentase 47,42\% kategori kurang baik.

4. Mengoptimalkan partisipasi masyarakat dalam perencanaan pembangunan fisik dengan persentase $47,68 \%$ kategori kurang baik.

5. Menjamin tercapainya sumber daya efektif, efisien, dan adil $49,23 \%$ kurang baik.

Pembangunan fisik persentase paling tertinggi dan paling terendah pada penelitian ini. Persentase tertinggi dan terendah berdasarkan penelitian ini dalam teori (Sjafrizal, 2014) yaitu indikator :

1. Integritas sinkronisasi antara perencanaan dan pengawasan, dalam hal perencanaan 
pembangunan fisik dalam musrenbang desa yang menempati persentase tertinggi yaitu $57,9 \%$ kategori baik.

2. Menjamin terciptanya integritas sinkronisasi antara perencanaan, pelaksanaa dan pengawasan, dalam hal perencanaan pendanaan dalam pembangunan fisik persentase $42,27 \%$ kategori kurang baik.

Berdasarkan hasil output spss persentase tertinggi dan terendah faktorfaktor yang memengaruhi peranan kepemimpinan kepala desa dalam teori (S., 2013):

1. Sumber daya manusia dalam peranan kewajiban kerja aparatur desa dalam pembangunan fisik dengan hasil output spss memiliki persentase $(7 \%)$ berpengaruh.

2. Sumber dana dalam peranan aparatur dalam hal pembangunan fisik dengan hasil output spss memiliki persentase $(21 \%)$ berpengaruh.

3. Faktor partisipasi masyarakat dalam peranan kesadaran masyarakat dalam pelakasanaan pembangunan fisik dengan hasil output spss memiliki persentase $(29 \%)$ berpengaruh.

Perumusan masalah dan pengambilan keputusan apakah faktor sumber daya manusia memengaruhi peranan kepemimpinan kepala desa . pengambilan keputusan dimana peranan kepemimpinan kepala desa adalah $(X)$ dan faktor sumber daya manusia adalah $(Y)$ pengujian Hipotesis dengan cara pertama : Jika : sig > 0,05 maka Ho diterimah, sig < 0,05 maka Ho ditolak. Diketahui dari hasil spps pada kolom Coefficients $^{\mathrm{a}}$ di atas untuk pengaruh $\mathrm{x}$ dan $\mathrm{y}$ adalah sebesar sig $0,000<0,05$ Ho ditolak berarti Ha diterima yang berarti faktor sumber daya manusia memiliki pengaruh terhadap peranan kepemimpinan kepala desa karena tingkat signifikan tidak melebihi level of significant 0,00 . Pengujian dengan cara uji $f$ : Jika : nilai sig < 0,05 atau $f$ hitung > $f$ Tabel maka terdapat pengaruh $\mathrm{x}$ secara simultan terhadap y Jika : nilai sig > 0,05 atau $f$ hitung < $f$ Tabel maka tidak terdapat pengaruh $x$ terhadap y dengan rumus uji $f$ sebagai berikut dan titik persentase distribusi $F$ untuk probabilitas 0,05: $\mathrm{f}$ tabel : $\mathrm{f}(\mathrm{k} ; \mathrm{n}-\mathrm{k})=\mathrm{f}(2$ $; 97-2)=(2 ; 95)=3.09$.

Hasil keputusan diketahui dari penelitian diatas untuk mengetahui faktor pengaruh $x$ terhadap y dengan nilai $f$ hitung
6,50 , f tabel 3.09 berarti faktor sumber daya manusia memiliki pengaruh terhadap peranan kepemimpinan kepala desa karena $F$ hitung lebih besar dari $F$ tabel. Berdasarkan output spss dinyatakan bahwa ada faktor sumber daya manusia memiliki pengaruh terhadap peranan kepemimpinan kepala desa dapat dilihat pengaruhnya dalam hasil spss Model Summary pada R Square sebesar $0.07 \times 100 \%=7 \%$. Hal ini mengandung arti bahwa $7 \%$ faktor sumber daya manusia memiliki pengaruh terhadap peranan kepemimpinan kepala desa.

Perumusan masalah dan pengambilan keputusan apakah faktor sumber dana memengaruhi peranan kepemimpinan kepala desa. Pengambilan keputusan dimana peranan kepemimpinan kepala desa adalah (X) dan faktor sumber dana adalah (Y) pengujian hipotesis dengan cara pertama : jika : sig > 0,05 maka Ho diterima sig < 0,05 maka Ho ditolak. Diketahui dari hasil spps pada kolom Coefficients $^{a}$ diatas untuk pengaruh $x$ dan y adalah sebesar sig 0,000 < 0,05 Ho ditolak berarti $\mathrm{Ha}$ di terima yang berarti faktor sumber dana memiliki pengaruh terhadap peranan kepemimpinan kepala desa karena tingkat signifikan tidak melebihi level of significant 0,00 . Pengujian dengan cara uji $f$, jika : nilai sig < 0,05 atau $f$ hitung > $f$ tabel maka terdapat pengaruh $x$ secara simultan terhadap y, jika : nilai sig > 0,05 atau $f$ hitung \& $f$ tabel maka tidak terdapat pengaruh $x$ terhadap y. Dengan rumus uji $f$ sebagai berikut dan titik persentase distribusi F untuk probabilitas 0,05 : $f$ tabel : $f(k ; n-k)$ $=f(2 ; 97-2)=(2 ; 95)=3.09$.

Hasil keputusan diketahui dari penelitian di atas untuk mengetahui faktor pengaruh $x$ terhadap y dengan nilai $f$ hitung 2.044 , f tabel 3.09 berarti faktor sumber dana memiliki pengaruh terhadap peranan kepemimpinan kepala desa karena $F$ hitung lebih besar dari $\mathrm{F}$ tabel. Berdasarkan output spss dinyatakan bahwa ada pengaruh berarti faktor sumber dana memiliki pengaruh terhadap peranan kepemimpinan kepala desa dapat di lihat pengaruhnya dalam hasil spss Model Summary pada $\mathrm{R}$ Square sebesar $0.21 \times 100 \%=21 \%$. Hal ini mengandung arti bahwa $21 \%$ faktor sumber dana memiliki pengaruh terhadap peranan kepemimpinan kepala desa.

Perumusan masalah dan pengambilan keputusan apakah faktor partisipasi masyarakat memengaruhi peranan 
kepemimpinan kepala desa. Pengambilan keputusan dimana peranan kepemimpinan kepala desa adalah $(X)$ dan faktor partisipasi masyarakat adalah ( $\mathrm{Y}$ ) pengujian Hipotesis dengan cara pertama : jika : sig > 0,05 maka Ho diterima sig < 0,05 maka Ho ditolak. Di ketahui dari hasil spps pada kolom Coefficients $^{a}$ diatas untuk pengaruh $\mathrm{x}$ dan $\mathrm{y}$ adalah sebesar sig $0,000<0,05$ Ho ditolak berarti $\mathrm{Ha}$ di terima yang berarti faktor partisipasi masyarakat memiliki pengaruh terhadap peranan kepemimpinan kepala desa karena tingkat signifikan tidak melebihi level of significant. Pengujian dengan cara uji $f$ : jika, nilai sig < 0,05 atau $f$ hitung > $f$ Tabel maka terdapat pengaruh $\mathrm{x}$ secara simultan terhadap y jika : nilai sig > 0,05 atau $f$ hitung < $f$ Tabel maka tidak terdapat pengaruh $x$ terhadap $y$ dengan rumus uji $f$ sebagai berikut dan titik persentase distribusi $F$ untuk probabilitas 0,05 : $\mathrm{f}$ tabel : $\mathrm{f}(\mathrm{k} ; \mathrm{n}-\mathrm{k})=\mathrm{f}(2$; $97-2)=(2 ; 95)=3.09$.

Hasil keputusan di ketahui dari penelitian di atas untuk mengetahui faktor pengaruh $x$ terhadap y dengan nilai $f$ hitung 2.801 , f tabel 3.09 berarti faktor partisipasi masyarakat memiliki pengaruh terhadap peranan kepemimpinan kepala desa karena $F$ hitung lebih besar dari $F$ tabel. Berdasarkan output spss dinyatakan bahwa partisipasi masyarakat memiliki pengaruh terhadap peranan kepemimpinan kepala desa dapat dilihat pengaruhnya dalam hasil spss Model Summary pada $\mathrm{R}$ Square sebesar $0.29 \times 100 \%=29 \%$. Hal ini mengandung arti bahwa $29 \%$ faktor partisipasi masyarakat memiliki pengaruh terhadap peranan kepemimpinan kepala desa.

\section{KESIMPULAN}

Berdasarkan pembahasan diatas, maka hal ini dapat disimpulkan dsebagai berikut:

1. Pembangunan fisik di desa Kulo Kecamatan Kulo Kabupaten Sidenreng Rappang berada pada kategori kurang baik dengan persentase $48,77 \%$. Hal ini menandakan bahwa kepemimpinan kepala desa masih kurang baik dalam menangani masalah peningkatan pembangunan fisik di Desa Kulo Kecamatan Kulo Kabupaten Sidenreng Rappang, dengan hasil ideal data akumalasi akhir pada kedua variabel Peranan kepemimpinan kepala desa dalam pembangunan fisik di Desa Kulo
p-ISSN 2302-0970

e-ISSN 2723-0201

Kecamatan Kulo Kabupaten Sidenreng Rappang yaitu persentase $50 \%$ kategori kurang baik.

2. Faktor-faktor yang memengaruhi peranan kepemimpinan kepala desa dalam pembangunan fisik di Desa Kulo Kecamatan Kulo Kabupaten Sidenreng Rappang.a). Faktor sumber daya manusia dengan persentase $7 \%$ b). Faktor sumber dana dengan persentase $21 \%$ dan c). Faktor partisipasi masyarakat dengan persentase $29 \%$. Dengan melihat hasil output spss di atas menandakan bahwa ke tiga indikator peranan kepemimpinan kepala desa dalam pembangunan fisik memiliki pengaruh.

\section{E. REFERENSI}

Basri, Y. Z. (2005). Keuangan Negara dan Analisis Kebijakan Utang Luar Negeri. Jakarta: PT. Raja Grafindo.

dkk, M. (2013). Pemberdayaan Masyarakat dalam Perspektif Pebijakan Publik. Bandung: Alfabeta.

Hasibuan, M. (2003). Organisasi dan Motivasi Dasar Peningkatan Produktivitas. Jakarta: Bumi Aksara.

S., M. d. (2013). Ekstrinsikalitas Sastra Indonesia. Jakarta: Rineka Cipta.

Saiman, L. (2009). Kewirausahaan Teori, Praktik dan Kasus-kasus. Jakarta: Salemba Empat.

Sjafrizal. (2014). Perencanaan Pembangunan Daerah dalam Era Otonomi. Jakarta: PT. Raja Grafindo Persada.

Soetomo. (2008). Masalah Sosial dan Upaya Pemecahannya. Yogyakarta: Pustaka Pelajar.

Sunyoto, D. (2012). Teori, Kusioner, dan Analisis Data Sumber Daya Manusia. Yogyakarta: PT. Buku Seru .

Tjokromidjojo, H. B. (2003). Reformasi Nasional dan Penyelenggara Good Governance dan perwujudan Masyarakat Madani. Bandung: Tokjominodjo. 